\title{
Relative Efficacy of Herbicides for Weed Control in Rice: A Review
}

\author{
Abhinandan Singh ${ }^{1 *}$ and Amit Kumar Singh ${ }^{2}$ \\ ${ }^{1}$ NRM, CEDA Project, Banda University of Agriculture and Technology, Banda, \\ U.P., India \\ ${ }^{2}$ Department of Agronomy, Banda University of Agriculture and Technology, \\ Banda, U.P., India \\ *Corresponding Author: Abhinandan Singh, NRM, CEDA Project, Banda University \\ of Agriculture and Technology, Banda, U.P., India.
}

Received: January 30, 2020

Published: February 08, 2020

(C) All rights are reserved by Abhinandan

Singh and Amit Kumar Singh.

\begin{abstract}
Rice farming is generally practiced in warm/cool humid subtropics where lack of control over the water by both flooding and drought problems and serious weed infestation thus crop badly suffer. Worldwide, weeds are one of the major biological threats to higher rice productivity and its management in rice is challenging, complex, expensive, and regulated mechanism. Therefore, to control the diverse weed infestation in rice fields, planed weed management strategies have to addressed. Now a day, unavailability of labour due to seasonal migration and lack of farm operations in the peak of the rice growing period adds fossil to the burning complications "the profuse weed infestation" and hence, the precise weed removal/control is utmost required to optimize the yield sustainability and efficient resource use. Among all the weed control methods, chemical weed control is commonly used to overcome weeds infestation which is easy, quick, time saving, cost effective and the most reliable method to control weeds in rice. In view of the limitations of herbicidal resistance of old molecules, it is necessary to promote the potential new molecules of herbicides and their combination (a sustainable option in a long run) for effective weed control. Among the existing herbicides, pre emergence herbicides alone are extensively used for controlling the rice weeds which do not provide extended period of weed control. To control weeds during the critical period of crop weed and escape the development of resistance, a combination of different groups of herbicides having different mode of action to be applied. Integrated approaches for weed management, emphasizing on the combination of management practices and scientific knowledge, may also reduce the economic costs and improve weed control owing to the complexity of the weed community.

Keywords: Chemical Methods; Herbicides; Resistance; Mode of Action
\end{abstract}

\section{Introduction}

Rice (Oryza sativa L.) is one of the most important field crop after wheat in the world providing staple food to the millions. It is an indispensable source of calories for almost half of the population in Asia. More than $90 \%$ of the world rice is produced and consumed in Asia, which is a native for $60 \%$ of the earth's population. With the increasing food demand by the growing population, rice will continue to be primary source of food. Rice is primary food crop of India and therefore, national food security system largely depends on productivity of rice ecosystems. The world's total area under rice is $161.1 \mathrm{mha}$ and production is about $480.3 \mathrm{mt}$ along with the productivity of $2.98 \mathrm{t} / \mathrm{ha}$ [1]. Rice is the first most important crop in India where it is grown in an area of 44.1 mha with an annual production of $106.7 \mathrm{mt}$ and average productivity is $2.4 \mathrm{t} / \mathrm{ha}$. However, in Bihar, rice is being cultivated on 32.2 lakh ha area with the production of 64.89 lakh tonns having productivity $2.02 \mathrm{t} / \mathrm{ha}$ [2]. Rice is grown in both kharif and Rabi seasons under diverse ecological and climatic conditions apart from socio-economic diversities of the state. $33 \%$ of total rice land has got irrigation facilities and rest is totally dependent upon rainfall. Among various depressing factors, abiotic stress i.e. water and nutrient stress and biotic stress i.e. weed infestations in the field are the most crucial factors due to which rice production is unpredictable and considerably low. Weeds not only reduce rice production but also have an adverse effect on rice grain quality. Hand weeding is the most effective method, however, high labour wages and non-availability of labour during peak periods of agricultural operations, timely weeding is not possible. Most of the pre-emergence herbicides viz., butachlor, pretilachlor and thiobencarb were applied in large quantities for weed management in transplanted rice. These herbicides are very effective for grasses and less effective against sedges and broad-leaved weeds (Singh., et al. 2009). Further, these herbicides are very effective for controlling weeds up to 20 DAT. Application of herbicide mixtures or sequential application of herbicides may be useful for broad-spectrum control of weeds in rice. Recent trend of herbicide use is to find out an alternative and effective weed management by using low dose high efficiency herbicides, which will not only reduce the total volume of herbicide per unit area, but also application becomes easier and economical to the farmer. 
Weeds flora in rice field

\begin{tabular}{|c|c|c|c|c|c|}
\hline Weeds & $\begin{array}{c}\text { Botanical } \\
\text { name }\end{array}$ & $\begin{array}{c}\text { English } \\
\text { name }\end{array}$ & $\begin{array}{c}\text { Common } \\
\text { name }\end{array}$ & Family & $\begin{array}{c}\text { Habi- } \\
\text { tat }\end{array}$ \\
\hline \multirow[t]{9}{*}{ Grasses } & $\begin{array}{l}\text { Cynodon dacty- } \\
\text { lon (L.) Pers }\end{array}$ & $\begin{array}{c}\text { Bermuda } \\
\text { grass }\end{array}$ & $\begin{array}{l}\text { Doob } \\
\text { grass }\end{array}$ & Poaceae & $\begin{array}{c}\text { Peren- } \\
\text { nial }\end{array}$ \\
\hline & $\begin{array}{l}\text { Echinochloa } \\
\text { crusgalli (L.) } \\
\text { Beauv }\end{array}$ & $\begin{array}{c}\text { Barnyard } \\
\text { grass }\end{array}$ & $\begin{array}{l}\text { Shyma } \\
\text { ghas }\end{array}$ & Poaceae & $\begin{array}{l}\text { An- } \\
\text { nual }\end{array}$ \\
\hline & $\begin{array}{c}\text { Echinochloa } \\
\text { colonum (L.) } \\
\text { Link }\end{array}$ & Jangli rice & $\begin{array}{c}\text { Senwai/ } \\
\text { Dhenhari }\end{array}$ & Poaceae & $\begin{array}{l}\text { An- } \\
\text { nual }\end{array}$ \\
\hline & $\begin{array}{l}\text { Eleusine indica } \\
\text { (L.) Gaerth }\end{array}$ & $\begin{array}{l}\text { Goose } \\
\text { grass }\end{array}$ & Kodai & Poaceae & $\begin{array}{l}\text { An- } \\
\text { nual }\end{array}$ \\
\hline & $\begin{array}{c}\text { Digitaria } \\
\text { sanguinalis (L.) } \\
\text { Scop. }\end{array}$ & $\begin{array}{l}\text { Crab } \\
\text { grass }\end{array}$ & $\begin{array}{l}\text { Hindu } \\
\text { Behar }\end{array}$ & Poaceae & $\begin{array}{l}\text { An- } \\
\text { nual }\end{array}$ \\
\hline & $\begin{array}{l}\text { Dactyloctenium } \\
\text { aegyptium (L.) } \\
\text { P. Beauv }\end{array}$ & $\begin{array}{c}\text { Crow foot } \\
\text { grass }\end{array}$ & $\begin{array}{c}\text { Ma- } \\
\text { karaghas }\end{array}$ & Poaceae & $\begin{array}{l}\text { An- } \\
\text { nual }\end{array}$ \\
\hline & Oryza sativa & $\begin{array}{l}\text { Weedy } \\
\text { rice }\end{array}$ & $\begin{array}{l}\text { Weedy } \\
\text { rice }\end{array}$ & Poaceae & $\begin{array}{l}\text { An- } \\
\text { nual }\end{array}$ \\
\hline & $\begin{array}{l}\text { Panicum repens } \\
\text { Linn. }\end{array}$ & $\begin{array}{l}\text { Panic } \\
\text { grass }\end{array}$ & Debhar & Poaceae & $\begin{array}{l}\text { An- } \\
\text { nual }\end{array}$ \\
\hline & $\begin{array}{l}\text { Paspalum disti- } \\
\text { chum } \mathrm{L}\end{array}$ & $\begin{array}{l}\text { Hiiograss/ } \\
\text { Knot grass }\end{array}$ & $\mid \begin{array}{c}\text { Naadi } \\
\text { Ghas/ } \\
\text { Badi doob }\end{array}$ & Poaceae & $\begin{array}{c}\text { Peren- } \\
\text { nial }\end{array}$ \\
\hline \multirow[t]{4}{*}{ Sedges } & $\begin{array}{l}\text { Cyperus rotun- } \\
\text { dus Linn }\end{array}$ & $\begin{array}{c}\text { Purple nut } \\
\text { sedge }\end{array}$ & Motha & $\begin{array}{c}\text { Cypera- } \\
\text { ceae }\end{array}$ & $\begin{array}{c}\text { Peren- } \\
\text { nial }\end{array}$ \\
\hline & $\begin{array}{c}\text { Cyperus iria } \\
\text { Linn }\end{array}$ & $\begin{array}{c}\text { Yellow nut } \\
\text { sedge }\end{array}$ & Bhada & $\begin{array}{l}\text { Cypera- } \\
\text { ceae }\end{array}$ & $\begin{array}{c}\text { Peren- } \\
\text { nial }\end{array}$ \\
\hline & $\begin{array}{l}\text { Cyperus diffor- } \\
\text { mis Linn }\end{array}$ & $\begin{array}{l}\text { Paddy } \\
\text { motha }\end{array}$ & Jhirua & $\begin{array}{l}\text { Cypera- } \\
\text { ceae }\end{array}$ & $\begin{array}{c}\text { Peren- } \\
\text { nial }\end{array}$ \\
\hline & $\begin{array}{l}\text { Fimbristylis mili- } \\
\text { aceae (L.) Vahl }\end{array}$ & - & Banchitra & $\begin{array}{l}\text { Cypera- } \\
\text { ceae }\end{array}$ & $\begin{array}{c}\text { Peren- } \\
\text { nial }\end{array}$ \\
\hline \multirow{9}{*}{$\begin{array}{l}\text { B r o a d } \\
\text { l e a v e c } \\
\text { weeds }\end{array}$} & \begin{tabular}{|c|} 
Amaranthus \\
viridis Linn
\end{tabular} & Pigweed & $\begin{array}{c}\text { Jangli } \\
\text { chaulai }\end{array}$ & $\begin{array}{l}\text { Amaran- } \\
\text { thaceae }\end{array}$ & Annual \\
\hline & $\begin{array}{l}\text { Ammannia bac- } \\
\text { cifera (L.) Roxb }\end{array}$ & Red stem & $\begin{array}{c}\text { Jangli } \\
\text { mehandi }\end{array}$ & \begin{tabular}{|c} 
Lythra- \\
ceae
\end{tabular} & Annual \\
\hline & $\begin{array}{l}\text { Caesulia axillar- } \\
\text { ies (L.) Rottb }\end{array}$ & Ghrilla & - & $\begin{array}{c}\text { Composi- } \\
\text { tae }\end{array}$ & Annual \\
\hline & \begin{tabular}{|c|} 
Commelina \\
benghalensis \\
Linn
\end{tabular} & $\begin{array}{l}\text { Day } \\
\text { flower }\end{array}$ & Kankaua & \begin{tabular}{|c} 
Com- \\
melinace- \\
ae
\end{tabular} & Annual \\
\hline & $\begin{array}{c}\text { Eclipta alba (L.) } \\
\text { Hassk }\end{array}$ & Mukand & Bhangra & $\begin{array}{c}\text { Composi- } \\
\text { tae }\end{array}$ & $\begin{array}{l}\text { An- } \\
\text { nual }\end{array}$ \\
\hline & $\begin{array}{l}\text { Euphorbia } \\
\text { hirta Linn }\end{array}$ & $\begin{array}{l}\text { Asthma } \\
\text { plaub }\end{array}$ & $\begin{array}{c}\text { Bari } \\
\text { doodhi }\end{array}$ & $\begin{array}{l}\text { Euphor- } \\
\text { biaceae }\end{array}$ & $\begin{array}{l}\text { An- } \\
\text { nual }\end{array}$ \\
\hline & $\begin{array}{l}\text { Phyllanthus } \\
\text { niruri Linn }\end{array}$ & $\begin{array}{c}\text { Haz- } \\
\text { ardana }\end{array}$ & - & $\begin{array}{l}\text { Euphor- } \\
\text { biaceae }\end{array}$ & $\begin{array}{l}\text { An- } \\
\text { nual }\end{array}$ \\
\hline & $\begin{array}{c}\text { Ludwigia } \\
\text { parviflora Linn }\end{array}$ & - & $\begin{array}{c}\text { Water } \\
\text { purslane }\end{array}$ & $\begin{array}{l}\text { Onagra- } \\
\text { ceae }\end{array}$ & $\begin{array}{l}\text { An- } \\
\text { nual }\end{array}$ \\
\hline & $\begin{array}{l}\text { Spilanthes ac- } \\
\text { mella Murr. }\end{array}$ & - & - & $\begin{array}{l}\text { Astera- } \\
\text { ceae }\end{array}$ & $\begin{array}{l}\text { An- } \\
\text { nual }\end{array}$ \\
\hline
\end{tabular}

Table 1

Losses due to weed

Weed competes with the crop plants in the field for nutrients, moisture and sunlight. The nature and severity of weed competition depend on (a) types of weed species, (b) intensity of infesta- tion, (c) duration of weed infestation, (d) competing ability of the crop plants and (e) soil-climate conditions which affect the crop and weed growth. Reduction in grain yield is directly correlated with the severity of weed competition. The prominent weed flora appearing in the rice field at different stages of crop growth under varied environmental situation differed because different species of weed flora required different agro-ecosystem. Grassy weeds were heavy competitors with rice crop and were followed by sedges and broad leaved weeds [3]. Kumar., et al. [4] reported that the reduction in grain yield of rice due to uncontrolled weeds in weedy plot was $70.4 \%$ during 2006 and 67.4 percent during 2007 as compared to weed control treatments. Puniya., et al. [5] noticed that the highest loss of nutrients were occurred in unweeded (42.07, 10.00 and $21.80 \mathrm{~kg} \mathrm{NPK} / \mathrm{ha}$ ) due to more density and dry weight of weeds in rice during kharif in silt loam soil of Pantnagar.

Description of herbicides use in rice field

\begin{tabular}{|l|l|}
\hline Common name & Bispyribac-sodium \\
\hline Substance group & Pyrimidinylcarboxy compound \\
\hline Chemical formula & $\mathrm{C}_{19} \mathrm{H}_{17} \mathrm{~N}_{4} \mathrm{NaO}_{8}$ \\
\hline Substance origin & Synthetic \\
\hline Chemical name & $\begin{array}{l}\text { Sodium 2,6-bis [4, 6-dimethoxypyrami- } \\
\text { din-2-yl) oxy] }\end{array}$ \\
\hline Trade name & Nominee gold \\
\hline $\begin{array}{l}\text { Formulation and } \\
\text { Active ingredient }\end{array}$ & Soluble concentration $(10 \%)$ \\
\hline Time of application & Post-emergence (20-25 DAT) \\
\hline Type of Herbicide & Systemic \\
\hline Mode of action & $\begin{array}{l}\text { Selective, systemic action absorbed by } \\
\text { foliage and roots. Inhibits plant amino } \\
\text { acid synthesis - acetohydroxyacid syn- } \\
\text { thase AHAS. }\end{array}$ \\
\hline Structural Formula & $\mathrm{CH}_{3} \mathrm{O}$ \\
\hline
\end{tabular}

Table 2

\begin{tabular}{|l|l|}
\hline Common name & Pretilachlor \\
\hline Substance group & Chloroacetamide \\
\hline Chemical formula & $\mathrm{C}_{17} \mathrm{H}_{26} \mathrm{CINO}_{2}$ \\
\hline Substance origin & Synthetic \\
\hline Chemical name & $\begin{array}{l}\text { 2- Chloro-N- 92.6 diethyl phenyl) -N- (2- } \\
\text { propoxyethyl) acetamide }\end{array}$ \\
\hline Trade name & Rifit \\
\hline $\begin{array}{l}\text { Formulation and } \\
\text { Active ingredient }\end{array}$ & Emulsion Concentrate (50\%) \\
\hline Time of application & Pre-emergence (0-5 DAT) \\
\hline Type of Herbicide & Systemic \\
\hline Mode of action & $\begin{array}{l}\text { Selective, systemic action herbicide. Con- } \\
\text { trol annual grasses, broad-leaved weeds } \\
\text { and sedges in rice and works by inhibiting } \\
\text { cell division. }\end{array}$ \\
\hline
\end{tabular}




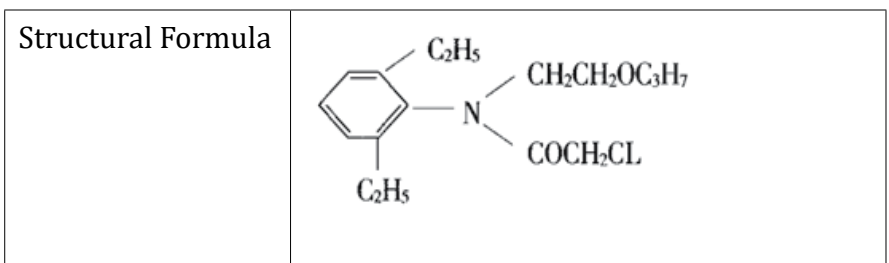

Table 3

\begin{tabular}{|l|l|}
\hline Common name & Pyrazosulfuron \\
\hline Substance group & Sulfonylurea \\
\hline Chemical formula & $\mathrm{C}_{14} \mathrm{H}_{18} \mathrm{~N}_{6} \mathrm{O}_{7} \mathrm{~S}$ \\
\hline Substance origin & Synthetic \\
\hline Chemical name & $\begin{array}{l}\text { Ethyl } 5 \text { [N (4,6dimethoxypyrimidin2yl) } \\
\text { carbamoyl-sulfamoyl]1-mthyl-1H-pyr- } \\
\text { azole-4-carboxylate }\end{array}$ \\
\hline Trade name & Sathi \\
\hline Formulation and & Wettable powder (10\%) \\
\hline Time of application & Post-emergence (20 - 25 DAT) \\
\hline Type of Herbicide & Systemic \\
\hline Mode of action & $\begin{array}{l}\text { Broad-spectrum activity absorbed by } \\
\text { roots and translocated throughout plant } \\
\text { by controlling the synthesis of amino } \\
\text { acids. Inhibits plant amino acid synthesis } \\
\text { - acetohydroxyacid synthase AHAS }\end{array}$ \\
\hline Structural Formula & $\begin{array}{l}\mathrm{CH}_{3}-\mathrm{O} \\
\text { (n) }\end{array}$ \\
\hline
\end{tabular}

Table 4

\begin{tabular}{|l|l|}
\hline Common name & Butachlor \\
\hline Substance group & chloroacetamide \\
\hline Chemical formula & $\mathrm{C}_{17} \mathrm{H}_{26} \mathrm{ClNO}_{2}$ \\
\hline Substance origin & Synthetic \\
\hline Chemical name & $\begin{array}{l}\text { N-butoxymethyl- 2 Chloro-2, 6-diethyl } \\
\text { acetanilide }\end{array}$ \\
\hline Trade name & Machete \\
\hline $\begin{array}{l}\text { Formulation and } \\
\text { Active ingredient }\end{array}$ & $\begin{array}{l}\text { Emulsion Concentrate 60\% (w/v), Gran- } \\
\text { ule (5\%) }\end{array}$ \\
\hline Time of application & Pre-emergence \\
\hline Type of herbicide & Systemic \\
\hline Mode of action & $\begin{array}{l}\text { Selective, systemic absorbed primarily via } \\
\text { germinating shoots. Inhibition of VLCFA } \\
\text { (inhibition of cell division) control of } \\
\text { annual grasses and some broad-leaved } \\
\text { weed. }\end{array}$ \\
\hline Structural Formula & \multicolumn{2}{|c|}{$\mathrm{C}_{2} \mathrm{H}_{5}$} \\
$\mathrm{CH}_{2} \mathrm{O}_{\left(\mathrm{CH}_{2}\right)_{3} \mathrm{CH}_{3}} \mathrm{COCH}_{2} \mathrm{Cl}_{2}$
\end{tabular}

Table 5

\begin{tabular}{|c|c|}
\hline Common name & $2,4-\mathrm{D}$ \\
\hline Substance group & Chlorophenoxy compounds \\
\hline Chemical formula & $\mathrm{C}_{8} \mathrm{H}_{6} \mathrm{Cl}_{2} \mathrm{O}_{3}$ \\
\hline Substance origin & Synthetic of auxin \\
\hline Chemical name & $\begin{array}{l}\text { 2, 4-Dichlorophenoxy acetic acid ethyl } \\
\text { ester }\end{array}$ \\
\hline Trade name & $\begin{array}{l}\text { Barrage, Formula } 40, \text { Opt- amine, Weedar } \\
64 \text {, Plantgard and weedmar }\end{array}$ \\
\hline $\begin{array}{l}\text { Formulation and } \\
\text { Active ingredient }\end{array}$ & $\begin{array}{l}\text { Emulsion Concentrate (38\%), Dark amber } \\
\text { liquid }\end{array}$ \\
\hline Time of application & Post-emergence \\
\hline Type of Herbicide & Systemic and Selective \\
\hline Mode of action & $\begin{array}{l}\text { It is penetrate foliage, whereas plant roots } \\
\text { absorb the salt forms used on a wide } \\
\text { variety of terrestrial and aquatic broad- } \\
\text { leaf weeds. It has little effect on grasses. } \\
\text { Abnormal increases in cell wall plasticity, } \\
\text { biosynthesis of proteins, and production } \\
\text { of ethylene occur in plant tissues follow- } \\
\text { ing exposure, and these processes are } \\
\text { responsible for uncontrolled cell division. }\end{array}$ \\
\hline Structural Formula & \\
\hline
\end{tabular}

Table 6

\begin{tabular}{|l|l|}
\hline Common name & Pendimethalin \\
\hline Substance group & Dinitroaniline \\
\hline Chemical formula & $\mathrm{C}_{13} \mathrm{H}_{19} \mathrm{~N}_{3} \mathrm{O}_{4}$ \\
\hline Substance origin & Synthetic \\
\hline chemical name & $\begin{array}{l}\mathrm{N}-(1 \text {-ethylpropyl)-2, 6-dinitro-3, 4-Xyli- } \\
\text { dine }\end{array}$ \\
\hline Trade name & Stomp \\
\hline $\begin{array}{l}\text { Formulation and } \\
\text { Active ingredient }\end{array}$ & Emulsion Concentrate (33 and 40\%), \\
\hline Time of application & Pre-emergence, Post-emergence \\
\hline Type of Herbicide & Systemic and Selective \\
\hline Mode of action & $\begin{array}{l}\text { Selective, absorbed by roots and leaves and } \\
\text { control annual grasses. Inhibition of mito- } \\
\text { sis and cell division. } \mathrm{Microtubule} \mathrm{assembly}_{\text {inhibition }}\end{array}$ \\
\hline Structural Formula & \multicolumn{1}{|c|}{$\mathrm{NO}_{2}$} \\
\hline
\end{tabular}

Table 7

Research work done in India and abroad for weed control in rice by herbicides

Effect of herbicides on weeds in rice field

Herbicides effectively controlled the weed population and lowering weed dry matter production and it increase slowly towards maturity of the crop due to suppression of weed population at ear- 
ly stage of crop growth because of their broad spectrum activity that controlled most of the weed species. Hussain., et al. [6] carried out a field experiment at Lahore, Pakistan. They found that bispyribac-sodum proved the best weedicide with $90.5 \%$ weed control efficiency and paddy yield with $3.61 \mathrm{t} /$ ha which was comparatively higher than other weedicides. Dixit and Varshney [7] conducted a field trail to evaluate the post-emergence herbicides in direct seeded rice during the rainy season of 2001 and 2002 and reported that the post-emergence application of Pyrazosulfuron $25 \mathrm{~g} / \mathrm{ha}$ effectively controlled the infestation of Phyllanthus niruri, Alternanthera sessilis, Commalleina bengalensis, Physalis minima and Cyperus iria followed by one hand weeding. Incorporation of dhaincha by spraying $2,4-\mathrm{D}$ resulted in $78 \%$ reduction in total weed count and $59 \%$ in weed dry matter production. Application of 2, 4-D for incorporation of dhaincha controlled broad-leaved weeds and sedges substantially [8]. Shahbaz., et al. [9] found that the weed density was influenced by different herbicides in transplanted rice and showed significant differences at three locations during kharif 2015. All the treatments significantly suppressed the weed density as compared to weedy check at all the locations. The highest numbers of weeds $/ \mathrm{m}^{2}$ were recorded in weedy check $(91.00,67.34$ and 56.30) while the lowest weed populations were recorded in the plot treated with bispyribac sodium (7.66, 3.67 and 5.60) at all the three locations respectively. Vaishya and Tomar [10] reported that post-emergence application of 2,4-D @0.4kg/ha was formed promising in reducing the weed dry weight/unit area.

\section{Effect of herbicides on growth and yield of rice}

Growth and yield also significantly influenced by herbicides. This might be due to reduced state of crop-weed competition during critical growth stages. The plant did not face either the nutrients or moisture deficits caused by heavy weed infestation and enjoyed weed free condition during its peak vegetative and developmental phases. They grew freely to receive enough sunshine for carbohydrate synthesis resulting in better growth of plant, increased leaf area index, longer ear head, more number of effective tillers, more number of filled grains/spike and higher test weight. These ultimately resulted in increased grain yield of hybrid rice, Singh and Pandey [11]. The reduction of grain yield in weedy check was possibly due to severe weed infestation in the crop field. The weeds growing freely attained a vigour enough to complete with the crop plant for nutrient, moisture and sun-light throughout the growing season and thus suppress the crop plant resulted in reduced crop yield to greater extent Singh and Pandey [12]. These results are corroborated with findings of Kumar., et al. [13] and reported that plant height of transplanted rice was significantly higher with the application of bispyribac sodium $30 \mathrm{~g} /$ ha than other herbicides and weedy check. Ali., et al. [14] found that CGR, dry matter accumulation as well as LAI were high with the application of bispyribac sodium $25 \mathrm{~g} /$ ha than butachlor as well as mechanical and hand weeding throughout the crop period. Kumar., et al. [13] reported that among herbicides, significantly higher plant height, and dry matter accumulation were recorded in pyrazosulfuron $\mathrm{fb}$ bispyribac Sodium (150 g/ha PE fb 25g/ha POE) than weedy check.
Dixit., et al. [15] concluded that, the chemical weed control effectively controlled weeds were till the advanced growth stages of rice, which reduced weed competition favoring better utilization of available resources and it increases the grain and straw yield of crop.

\section{Effect of herbicides on nutrient uptake by rice}

Nutrient uptake by the rice is affected by the nutrient content in the total dry matter accumulated by the crop in its life cycle. This was fact that effective weed control measure increased the uptake of nutrients by the crop and decreased their removal by weeds. Finally the weed free crop absorbs higher quantity of nutrient from the soil than weedy check. However, in chemical weeding systems, lower depletion was recorded at early stage when steadily increased towards later stages of crop growth. Because of their persistence in soil, it controls the weeds over an extended period of time. As the degradation of herbicides occurs due to various chemical and bio-chemical processes, the killing effect also tend to decrease resulted in accumulation of high dry matter later stages of crop growth. Some finding was confirmed by Devi and Singh [16] reported that among weed management practices, application of bispyribac at $25 \mathrm{~g} / \mathrm{ha}+$ azimsulfuron at $17.5 \mathrm{~g} / \mathrm{ha}$ at 15-20 DAS established their superiority in minimizing the nitrogen removal by weeds which was significantly superior to other weed management treatments but it was next best to the hand weeding twice at 20 and 40 DAS. Kumar., et al. [4] found that uptake of nutrients was higher by direct seeded rice crop and decreased nutrient uptake by weeds with hand weedings and pre-emergence application of pendimethalin @1.0 kg/ha + anilophos @0.4 kg / ha over rest of the treatments.

\section{Effect of herbicides on economics of rice}

Chemical weed control always cost effective than other method of weed controls this might be due to less cost involved in chemical treatment per unit of yield obtained. It was observed that although, the yield was higher in hand weeded plot, the net return and B: C ratio were higher in chemical weeding (combined application of bispyribac-sodium + pyrazosulfuron). It was the cost investment in hand weeding which caused such differences. These findings were in agreement with Kaur and Singh [17] and Juraimi., et al. [18]. Hand weeding twice is still the most effective means to manage weeds in most of the crops but ever increasing efficacy of newly evolved herbicides and still faster increasing labour cost, making manual weeding a less desirable option. The also find support with the works of Kumaran., et al. [19] adoption of different weed management practices significantly influenced the gross returns, net returns and $\mathrm{B}: \mathrm{C}$ ratio. The treatment consisting of bispyribac sodium 10\% SC 40 g/ha registered Rs. 60,698 per ha as gross income next to weed free check Rs. 63,217 per ha with a net return of Rs. 38,970 per ha and a B: C ratio 2.79. This was followed by pretilachlor at $0.45 \mathrm{~kg} / \mathrm{ha}+\mathrm{HW}$ on 40 DAS with a gross return of Rs. 60,064 per ha, net return Rs. 36,171 per ha and B:C ratio 2.51 . Das., et al. [20] concluded that the post-emergence application of bispyribac-sodium $25 \mathrm{~g} /$ ha at 25 DAT proved economical herbicide for transplanted rice as compared to hand weeding twice and also other herbicides and weedy check. Singh and Namdeo [21] found 
higher net return (₹17,660/ha) and B : C ratio (2.57) under two hand weedings, which reduced to ₹9,847/ha and 2.26 under the application of butachlor. Also butachlor + 2, 4-D (EE) was comparable to two hand weedings wherein the net return and $\mathrm{B}$ : $\mathrm{C}$ ratio were observed to be ₹11,435/ha and 2.41 .

\section{Conclusion}

Weeds being the extreme serious pests in agriculture and have the excessive ability to compete with the crop for available resources (space, light, nutrient, CO2, water, air and etc.). Weed control in rice crop is always a problematic task for effective crop production as their presence causes severe reduction in yield and quality of crops thus reducing yield productivity and profitability. Herbicide applications is commonly used to overcome weed infestation which is easy, quick, time saving, cost effective and it is most reliable method to control weeds. Rice is grown in diverse agroecosystem therefore, weed communities and its types associated to rice fields are having huge variations. Hence, the use of a single herbicide cannot give satisfactory and cost-effective results of weed control. Integrated strategies on chemical weed management is the best option to control the diverse weeds flora and the competitive ability of weeds for the above and below ground resources. Regular monitoring and early detection of the evolution and mechanism of herbicide resistance is necessary. The adoption of suitable management strategies on herbicide is utmost important. Hence, in the future, researchers need to develop integrated weed management strategies along with effective herbicides which do not only favor crop yield and reduce weed infestation but also discourage the resistance of weed flora to herbicides.

\section{Bibliography}

1. Statista The statistics portal (2017).

2. Directorate of Economics Statistics, Govt. of India (2017).

3. Umapathy K and Sivakumar C. "Studies on crop- weed competition in rice-rice cropping system". (2000): 57.

4. Kumar J., et al. "Effect of weed management practices on nutrient uptake by direct seeded rice”. Oryza 47.4 (2010): 291-294.

5. Puniya R., et al. "Nutrient uptake by crop and weeds as influenced by trisulfuron, trisulfuron + pretilachlor and bensulfuron methyl in transplanted rice". Indian Journal of Weed Science 39 (2007): 239-240.

6. Hussain S., et al. "Weed management in direct seeded rice". The Journal of Animal and Plant Sciences 18 (2008): 86-88.

7. Dixit A and Varshney JG. "Assessment of post emergence herbicides in direct seeded rice". Indian journal of Weed Science 40 (2008): 144-147.

8. Anitha S., et al. "Concurrent growing of green manure with wet-seeded rice for cost-effective weed management". Indian Journal of Weed Science 44.1 (2010): 34-37.
9. Shahbaz MD., et al. "Effect of different post emergence herbicides on weed density and some agronomic attributes of transplanted rice in rice-wheat cropping system under adaptive research zone sheikhupura, Pakistan". Pakistan Journal of Weed Science Research 24 (2018): 1-8.

10. Vaishya RD and Tomar SK. "Weed control in puddled seeded rice (Oryza sativa L.) with herbicides". Indian Journal of Agronomy 45.2 (2000): 334-337.

11. Singh A and Pandey IB. "Effect of crop establishment methods, nutrient levels and weed management on yield of hybrid rice". Journal of Pharmacognosy and Phytochemistry 8.4 (2019): 9195.

12. Singh A and Pandey IB. "Effect of crop establishment methods, nutrient levels and weed management on yield attributing characters of hybrid rice". International Journal of Chemical Studies 7.3 (2019): 5153-5157.

13. Kumar J., et al. "Sowing time and weed management practices to enhance yield of direct-seeded rice". Indian Journal of Weed Science 44.4 (2013): 207-209.

14. Ali MN., et al. "Influence of herbicides on growth and profitability of transplanted rice (Oryza sativa L.) in Jharkhand". Journal of Pharmacognosy and Phytochemistry SP 1 (2018): 401-404.

15. Dixit A., et al. "Evaluation of direct-seeded rice drill against Japanese manual transplanter for higher productivity in rice". Indian Journal of Agricultural Science 80.10 (2010): 884-887.

16. Devi BR and Singh Y. "Effect of Nitrogen and Weed Management on Nutrient Removal by Weed in Direct Seeded Rice". International Journal of Current Microbiology and Applied Sciences 7.6 (2018): 1452-1459.

17. Kaur S and Singh S. "Bio-efficacy of different herbicides for weed control in direct-seeded rice." Indian Journal of Weed Science 47.2 (2015): 106-109.

18. Juraimi AS., et al. "Sustainable weed management in direct seeded rice culture: A review". Australian Journal of Crop Science 7.7 (2013): 989-1002.

19. Kumaran ST., et al. "Efficacy of new herbicide (bispyribacsodium $10 \%$ SC) against different weed flora, nutrient uptake in rice and their residual effects on succeeding crop of green gram under zero tillage". Journal of Applied and Natural Sciences 7.1 (2015): 279-285.

20. Das R., et al. "Weed management in transplanted rice through bispyribac-sodium $10 \%$ sc and its effect on soil microflora and succeeding crop blackgram". International Journal of Current Microbiology and Applied Sciences 4.6 (2017): 681-688. 
21. Singh RK and Namdeo KN. "Effect of fertility levels and herbicide on growth, yield and nutrient uptake of direct seeded rice". Indian Journal of Agronomy 49.1 (2004): 34-36.

\section{Assets from publication with us}

- Prompt Acknowledgement after receiving the article

- Thorough Double blinded peer review

- Rapid Publication

- Issue of Publication Certificate

- High visibility of your Published work

Website: www.actascientific.com/

Submit Article: www.actascientific.com/submission.php Email us: editor@actascientific.com

Contact us: +919182824667 